\title{
The effect of serum insulin on the blood pressure responses after oral glucose load in lean and centrally obese adult male subjects
}

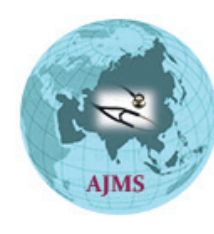

\author{
Thiri Win Htein ${ }^{1}$, Zarli Thant ${ }^{2}$, Ohn Mar ${ }^{3}$ \\ ${ }^{1}$ Assistant Lecturer, ${ }^{2}$ Professor, ${ }^{3}$ Professor and Head, Department of Physiology, University of Medicine 1, Yangon
}

Background: The vasodilator action of insulin might contribute to the reduction of blood pressure in the postprandial state and it remains to be clarified whether this action is impaired in the insulin- resistant obese state or not. Aims and Objective: The present study aimed to determine the blood pressure responses after an oral glucose load in lean and insulin resistant centrally obese adult male subjects. Materials and Methods: This study was carried out in eleven lean and eleven centrally obese adult male subjects. After a $75 \mathrm{~g}$ oral glucose load, blood pressures were measured at 15-minute intervals and the serum insulin level was determined at 30-minute intervals for two hours. Blood pressure was measured by indirect sphygmomanometry and serum insulin concentration was analyzed by ELISA method. Results: All centrally obese subjects were insulin resistant (HOMA-IR $\geq 2.6$ ). After oral glucose load, the per cent change in glucose-stimulated insulin responses at 30 minutes $(626 \%$ vs $344 \%, p<0.05)$ and at 60 minutes $(756 \%$ vs $417 \%, p<0.01)$ were significantly greater in the lean group than the centrally obese group. The fall in postprandial blood pressures started at 15 minutes and returned to baseline values at 120 minutes. The per cent change in SBP at 15 minutes $(-2.2 \%$ vs $-1.2 \%, \mathrm{p}<0.05)$ and at 30 minutes $(-3.2 \%$ vs $-2.1 \%, p<0.05)$ were significantly greater in the lean group than the centrally obese group. Conclusion: The present findings suggest that attenuation in BP responses as well as a lesser change in glucose-stimulated insulin responses in the centrally obese subjects might be attributable to the presence of insulin resistance.

Key words: serum insulin; Blood pressure responses; Oral glucose load; Centrally obese

\section{Access this article online}

Website:

http://nepjol.info/index.php/AJMS DOI: 10.3126/ajms.v12i5.34248

E-ISSN: 2091-0576 P-ISSN: 2467-9100

Copyright (c) 2021 Asian Journal of Medical Sciences

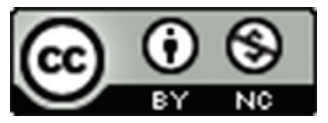

This work is licensed under a Creative Commons Attribution-NonCommercial 4.0 International License.

\section{INTRODUCTION}

The reduction in blood pressure after meal ingestion has been observed for a long time and Seyer-Hansen (1977) first recognized postprandial hypotension in a patient with Parkinson's disease. Postprandial hypotension means a decrease in systolic blood pressure of $20 \mathrm{mmHg}$ or more within 2 hours after oral glucose. ${ }^{1}$ The pathophysiology of postprandial hypotension is still unclear, probably multifactorial, including age or hypertension related impairments in baroreceptor reflex, insulin-induced vasodilatation, release of vasodilator peptides, excessive splanchnic blood pooling during digestion and impaired sympathetic nervous system compensation for meal ingestion. ${ }^{2}$
Insulin has actions on blood pressure through the phosphatidyl-inositol-3-kinase (PI3-K) pathway which involves in the generation of nitric oxide (NO), causing vasodilatation. ${ }^{3}$ It is proposed that the reduction of blood pressure in postprandial state could be contributed by insulin-induced vasodilatation. ${ }^{4}$ In addition, it is well known that obesity and insulin resistance are closely related. During insulin resistant state, there is an inability of insulin to produce its numerous actions including insulin-induced NO-mediated vasodilatation. ${ }^{5}$ However, our pervious study documented that postprandial hypotension was observed in elderly lean as well as elderly obese subjects, ${ }^{6}$ but the role of insulin resistance in postprandial hypotension was not determined. Therefore, the present study aimed to explore the blood pressure 
responses during postprandial period in lean and insulin resistant centrally obese adult male subjects.

\section{MATERIALS AND METHODS}

A quasi-experimental study with repeated measures was carried out in apparently healthy male subjects (age: 3060 years). They were explained about the procedure of the study and invited for voluntary participation. Written informed consent was taken. History taking and physical examination were done. Anthropometric measurements such as waist circumference, height and weight of the volunteers were measured and BMI was calculated.

For lean group, those with waist circumference: $\leq 90 \mathrm{~cm}$ and BMI $18.5-24.9 \mathrm{~kg} / \mathrm{m}^{2}$, fasting plasma glucose $<100 \mathrm{mg} / \mathrm{dL}$ and $\mathrm{SBP}<140 \mathrm{mmHg}$ and $\mathrm{DBP}<90 \mathrm{mmHg}$ were selected. For centrally obese group, those with waist circumference: $<90 \mathrm{~cm}$ and $\mathrm{BMI} \geq 25 \mathrm{~kg} / \mathrm{m}^{2}$, fasting plasma glucose: 100 to $125 \mathrm{mg} / \mathrm{dL}$ and SBP $<140 \mathrm{mmHg}$ and $\mathrm{DBP}<90 \mathrm{mmHg}$ were selected. The selected subjects were instructed to take 10 hours overnight fasting and come to the Postgraduate Research Laboratory, Department of Physiology, University of Medicine 1, Yangon in the next morning at 8:00 am. At the Research Laboratory, the blood pressure and heart rates were measured after 15 minute lying rest. After that, fasting blood samples were collected.

Then, the subjects were asked to take $75 \mathrm{~g}$ of glucose dissolved in $200 \mathrm{~mL}$ of water within five minutes. After the oral glucose load, the blood pressure and heart rates were measured at 15-minute intervals in supine position and the blood sample (about $2 \mathrm{~mL}$ ) was collected at 30-minute intervals up to 120 minutes for determination of serum insulin level. Blood was centrifuged at $3000 \mathrm{rpm}$ for 15 minutes to extract serum and serum was kept in the sealed tubes which were stored at $-20^{\circ} \mathrm{C}$ until analysis of serum insulin level. Insulin resistance was calculated by following formula (HOMA: Homeostatic Model Assessment) ${ }^{7}$.

$$
\text { HOMA-IR }=\frac{\text { Insulin }(\mu \mathrm{IU} / \mathrm{mL}) \times \text { Glucose }(\mathrm{mmol} / \mathrm{L})}{22.5}
$$

Statistical Package for the Social Sciences (SPSS) version 22 was used to analyse the data. Statistical significant level was determined at $\mathrm{p}<0.05$. Paired " $P$ " test was used to compare the blood pressure values before and after an oral glucose load in each group. Wilcoxon Signed-Rank test was used to compare the serum insulin levels before and after an oral glucose load in each group. To compare the parameters between two groups, Student's “ $l$ ' test and Mann-Whitney U test were used. For correlation study, Spearman's correlation coefficient was used. This study was done according to guideline of the Research and Ethical Committee of University of Medicine 1, Yangon.

\section{RESULTS}

Fasting plasma glucose was $87.64 \pm 5.92 \mathrm{mg} / \mathrm{dL}$ in the lean group and $109.64 \pm 8.19 \mathrm{mg} / \mathrm{dL}$ in the centrally obese group. Median and interquartile range of fasting serum insulin level was $10.1(9.5-10.8) \mu \mathrm{IU} / \mathrm{mL}$ in the lean group and 16.7 (14.9-33.6) $\mu \mathrm{IU} / \mathrm{mL}$ in the centrally obese group. There was significantly higher $(\mathrm{p}<0.001)$ fasting serum insulin in the centrally obese group than the lean group. HOMA-IR values in the lean and obese subjects were 2.2 (2.2-2.4) and 4.5 (4.2-9.3) respectively $(\mathrm{p}<0.001)$.

The patterns of blood pressure responses after oral glucose load in the lean and centrally obese adult male subjects are illustrated in Figure 1. The systolic mean and diastolic blood pressures fell after oral glucose load in both study groups, with maximum fall at 30 minutes. When compared between two groups, the per cent change in SBP at 15 minutes $(-2.2 \%$ vs $-1.2 \%, \mathrm{p}<0.05)$ and at 30 minutes $(-3.2 \%$ vs $-2.1 \%, \mathrm{p}<0.05)$ were significantly greater in the lean group than the centrally obese group.

There was no significant difference in the per cent change in DBP and MAP between the lean and centrally obese male subjects at all time points (Figure 2).

After oral glucose load, at 30, 60, 90 and 120 minutes, serum insulin level increased significantly from fasting level in both study groups $(\mathrm{p}<0.01)$ (Figure 3$)$.

Figure 4 shows comparison of the per cent change in serum insulin response after oral glucose load in the lean and centrally obese male subjects. The per cent change in serum insulin level after oral glucose load of the lean subjects was greater than that of the centrally obese male subjects at 30 minutes $(p<0.05)$ and at 60 minutes $(p<0.01)$.

\section{DISCUSSION}

In the present study, the range of HOMA-IR values in the lean subjects was 1.4 to 2.5 and that of the centrally obese subjects was 3.1 to 15.9. This finding also confirmed that all centrally obese subjects participated in the present study are insulin-resistant and all lean subjects are insulin sensitive since the cut-off point for defining insulin resistance was HOMA $\geq 2.6{ }^{8}$

After oral glucose load, there was a definite reduction in blood pressures at 15 minutes, 30 minutes and 45 minutes in both study groups. The fall in blood pressures was noted 


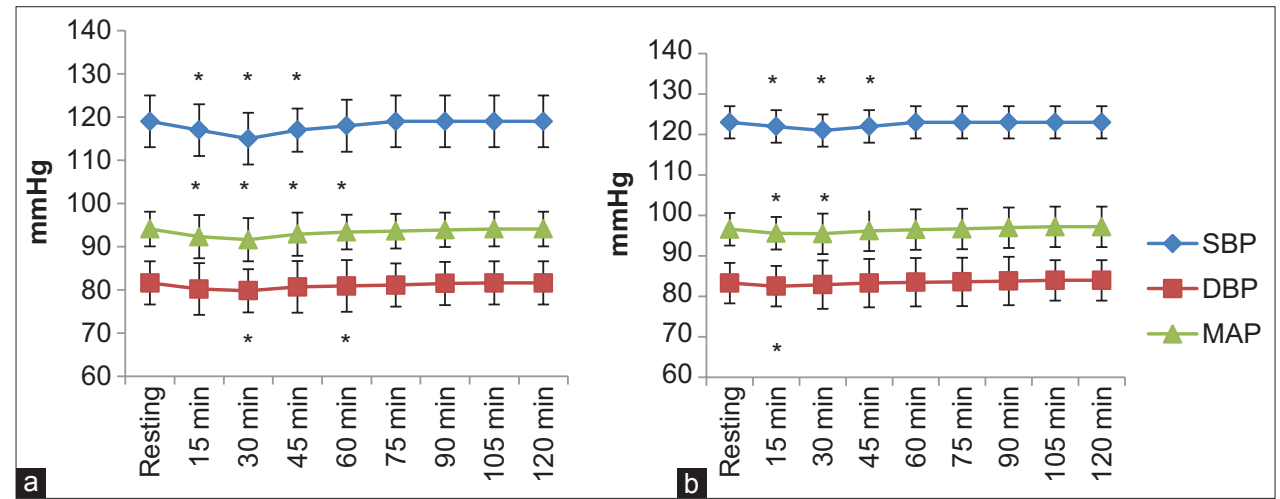

Figure 1: Blood pressure responses to oral glucose load in the lean (a) and centrally obese (b) adult male subjects * Significant difference in values between baseline and time points $(p<0.05)$

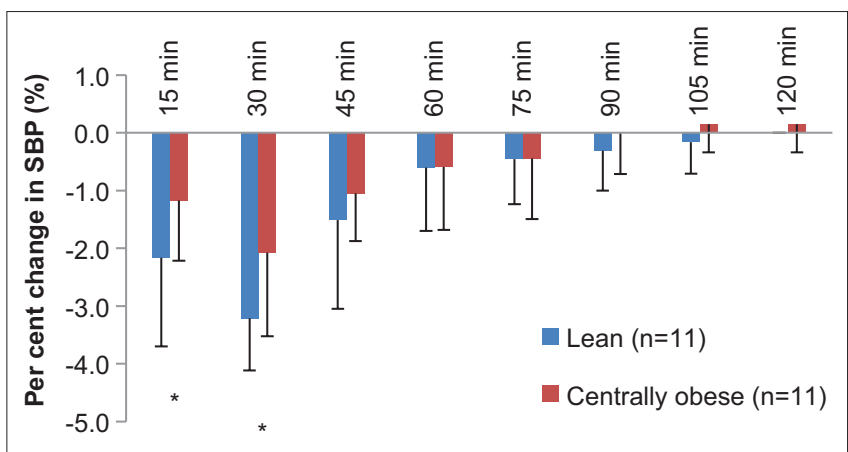

Figure 2: Per cent change in systolic blood pressure responses to oral glucose load in the lean and centrally obese adult male subjects *indicates significant difference between two groups $(p<0.05)$

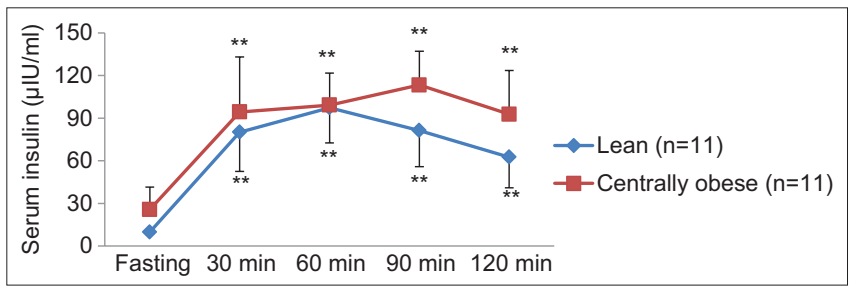

Figure 3: Comparison of serum insulin responses to oral glucose load in the lean and centrally obese adult male subjects * * Significant difference in values between fasting and time points $(p<0.01)$

at 15 minutes but maximal fall was recorded at 30 minutes after oral glucose load in both study groups. However, the magnitude of SBP fall at all time points were less than $20 \mathrm{mmHg}$, thus all the lean and centrally obese adult male subjects had no signs of postprandial hypotension. Then, SBP, DBP and MAP of both groups rose again and finally all BPs returned back to baseline values at 120 minutes. When BP responses between the lean and the centrally obese subjects were compared, the centrally obese subjects exhibited a lesser per cent change in BP responses at 15 minutes and 30 minutes.

The reduction in blood pressure following an oral glucose load found in the present study was in agreement with the previous studies. In these studies, a significant fall in

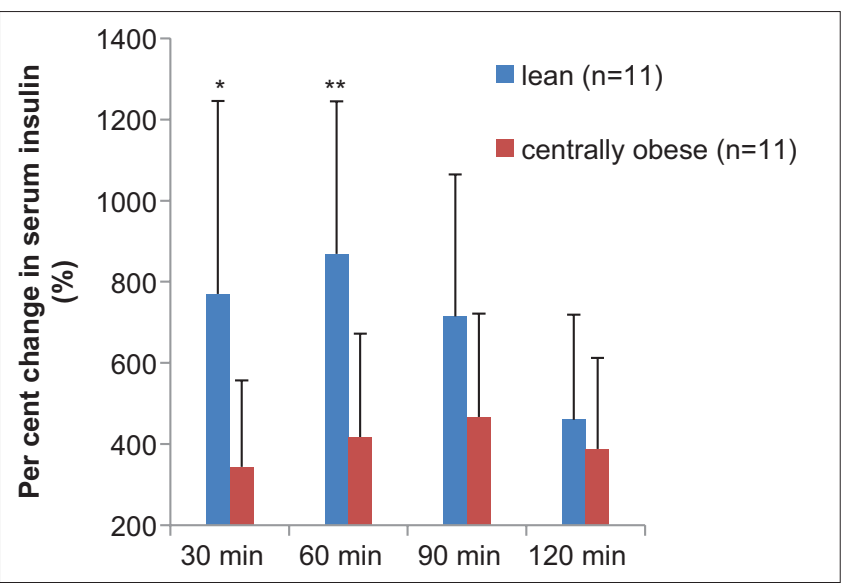

Figure 4: Per cent change in serum insulin responses to oral glucose load in the lean and centrally obese adult male subjects. *indicates significant difference between two groups $(p<0.05)$. ${ }^{* *}$ indicates significant difference between two groups $(p<0.01)$

BP was found at 15 minutes following oral glucose load or a meal and reached maximal fall at 60 minutes. The magnitude of fall in BPs was comparable with that of a study in which the age range of the participants was found to be similar to that of the present study. ${ }^{9}$ However, other studies exhibited a greater fall in BPs than the present study, as these studies were conducted in elderly (age of $>60$ years). ${ }^{6,10,11}$ Postprandial hypotension is recognized as a very common clinically relevant disorder in elderly persons. ${ }^{2}$

One of the proposed mechanisms for postprandial hypotension is insulin-induced vasodilatation following a meal by promoting NO release through PI3-K pathway. ${ }^{3}$ In the present study, a maximal fall in BP and significant per cent change in glucose-stimulated insulin response (626\% in the lean and $344 \%$ in the centrally obese subjects) were recorded at 30 minutes after oral glucose load. These findings suggested that a fall in BP might probably be due to splanchnic blood pooling following oral glucose load as a result of insulin-induced vasodilatation in both groups. 
The lesser glucose-stimulated insulin responses at 30 and 60 minutes in the centrally obese subjects in comparison with the lean subjects might be due to insulin resistant in obese subjects. Thus, it could be assumed that the attenuation of fall in BP following an oral glucose load in the centrally obese subjects might be due to impaired insulin induced vasodilatation as there was defect in nitric oxide synthesis during the insulin-resistant state. ${ }^{12}$ In conclusion, the present study suggests that glucosestimulated insulin responses might be involved in reduction of BP after oral glucose load.

\section{ACKNOWLEDGEMENT}

We are particularly grateful to Professor Dr. Zaw Wai Soe, Rector, University of Medicine 1, Yangon, for allowing us to undertake this study. We would like to express our special thanks to all the subjects involved in our study for their co-operation and participation.

\section{REFERENCES}

1. Seyer-Hansen K. Postprandial hypotension. British Medical Journal: 1977; 2:1262.

https://doi.org/10.1136/bmj.2.6097.1262

2. Jansen RWMM and Lipsitz LA. Postprandial hypotension: epidemiology, pathophysiology, and clinical management. Annals of Internal Medicine: 1995; 122:286-295.

https://doi.org/10.7326/0003-4819-122-4-199502150-00009

3. Zeng G, Nystrom FH, Ravichandran LV, Cong LN, Kirby M, Mostowski H, et al. Roles for insulin receptor, PI3-Kinase, and Akt in insulin-signaling pathways related to production of nitric oxide in human vascular endothelial cells. Circulation: 2000; 101: 1539-1545.

https://doi.org/10.1161/01.CIR.101.13.1539

4. Masuo K, Mikami H, Ogihara T and Tuck ML. Mechanisms mediating postprandial blood pressure reduction in young and elderly subjects. American Journal of Hypertension: 1996; 9(6):536-544.

https://doi.org/10.1016/0895-7061(95)00339-8

5. Vollenweider P, Randin D, Tappy L, Jequier E, Nicod P and Scherrer U. Impaired insulin-induced sympathetic neural activation and vasodilation in skeletal muscle in obese humans. The Journal of Clinical Investigation: 1994; 93(6):2365-2371. https://doi.org/10.1172/JCl117242

6. Zarli-Thant Blood pressure and leptin responses to meal in elderly obese and diabetic women with intermittent fasting. Ph.D (Physiology) Thesis, 2015, University of Medicine 1, Yangon.

7. Matthews DR, Hosker JP, Rudenski AS, Naylor BA, Treacher DF and Turner RC. Homeostasis model assessment: insulin resistance and beta-cell function from fasting plasma glucose and insulin concentrations in man. Diabetologia:1985; 28:412-419. https://doi.org/10.1007/BF00280883

8. Hettihewa LM, Palangasinghe $S$, Jayasinghe $S S$, Gunasekara SW and Weerarathna TP. Comparison of insulin resistance by indirect methods - HOMA, Quicki and McAuley - with fasting insulin in patients with type 2 diabetes in Galle, Sri Lanka: A pilot study. Online Journal of Health and Allied Sciences: 2006; 5(1): 1-8.

9. Thida-Cho. A study of postprandial blood glucose and cardiovascular responses in young and middle-aged Myanmar male subjects. M. Med.Sc. (Physiology) Thesis, 2000, University of Medicine 1, Yangon.

10. Van Orshoven NP, Jansen PAF, Oudejans I, Schoon $Y$ and Oey PL. Postprandial Hypotension in Clinical Geriatric Patients and Healthy Elderly: Prevalence Related to Patient Selection and Diagnostic Criteria. J Aging Res. 2010; 243752. https://doi.org/10.4061/2010/243752

11. Vanis L, Hausken T, Gentilcore D, Rigda RS, Rayner CK, FeinleBisset $C$, et al. Comparative effects of glucose and xylose on blood pressure, gastric emptying and incretin hormones in healthy older subjects. British Journal of Nutrition. 2011; 105:1644-1651.

https://doi.org/10.1017/S0007114510005489

12. Scherrer $U$ and Sartori $C$. Defective nitric oxide synthesis: a link between metabolic insulin resistance, sympathetic overactivity and cardiovascular morbidity. European Journal of Endocrinology. 2000; 142:315-323.

https://doi.org/10.1530/eje.0.1420315

\section{Author's Contribution:}

TWH-Prepared concept, study design, review of literature and manuscript, analyzed data and interpreted; ZT- reviewed the literature and manuscript preparation; OM- revision of the manuscript, statistically analysis and interpretation.

Work Attributed to:

Department of Physiology, University of Medicine 1, Yangon

Orcid ID:

Dr. Thiri Win Htein- (1D) https://orcid.org/0000-0003-4923-5284

Dr. Zarli Thant- (i) https://orcid.org/0000-0003-0123-8638

Dr. Ohn Mar- it https://orcid.org/0000-0001-8063-8597

Source of Funding: None, Conflict of Interest: None. 